\title{
Macroeconomics, Economic Crisis and Electoral Outcomes: A National European Pool
}

\author{
Acta Politica, accepted
}

\begin{abstract}
An abundance of comparative survey research argues the presence of economic voting as an individual force in European elections, thereby refuting a possible ecological fallacy. But the hypothesis of economic voting at the aggregate level, with macroeconomics influencing overall electoral outcomes, seems less sure. Indeed, there might be a micrological fallacy at work, with the supposed individual economic vote effect not adding up to a national electoral effect after all. Certainly that would account for the spotty evidence linking macroeconomics and national election outcomes. We examine the possibility of a micrological fallacy through rigorous analysis of a large time-series cross-sectional dataset of European nations. From these results, it becomes clear that the macroeconomy strongly moves national election outcomes, with hard times punishing governing parties, and good times rewarding them. Further, this economy-election connection appears asymmetric, altering under economic crisis. Indeed, we show that economic crisis, defined as negative growth, has much greater electoral effects than positive economic growth. Hard times clearly make governments more accountable to their electorates.
\end{abstract}

\section{KEYWORDS}

Economic voting; Macroeconomics; Economic crisis; Time-Series-Cross-Sectional data; Micrological fallacy 
The first studies on economics and elections forged macrolevel links. Different macroeconomic indicators sometimes showed themselves determinants of national incumbent support, measured in votes or popularity. [See the reviews of Nannestad and Paldam (1994); Norpoth (1996); Lewis-Beck and Stegmaier (2000).] The inference is that democratic voters are economic, rewarding the government for good times, and punishing it for bad. However, this inference, reported by itself, remains suspect be cause of the ecological fallacy (Kramer, 1983; Robinson, 1950). That is, individual voters may not act this way, in which case observed national economy-election patterns are spurious. To counter this possibility, studies have moved to the microlevel, examining voters in election surveys. These efforts were initially on individual democracies - notably the United States, France, Denmark, the United Kingdom. [See, as examples, respectively, Kiewiet (1983); Lewis-Beck (1983); Borre (1997); Sanders (2003).] Then, investigations became evermore micro and comparative, stretching across larger and larger samples of nations (Duch and Stevenson, 2008; Lewis-Beck, 1988). Over a broad range of democracies, in time and space, survey work supports the economic voter hypothesis. [See the current reviews of Duch (2007); Hellwig (2010); Lewis-Beck and Stegmaier (2007).] With minor caveats, then, the ecological fallacy argument has not been sustained.

However, another classic, the fallacy of composition, has not received the scrutiny it deserves (Blackburn, 2008: 69). That fallacy occurs when the truth of the part is not true for the whole. An opposite of the ecological fallacy, we label it here the micrological fallacy, a usage paralleling the micro/macro distinction in economics (where what makes sense at the micro-level may not make sense at the macrolevel, as the notorious Paradox of Thrift illustrates). Specifically in election studies, while individual voters may appear to be economic voters, all voters taken together may not reflect the changing state of the economy. Put another way, the collective vote of the national electorate might not respond to national economic conditions, despite a seemingly supportive microfoundation. If this micrological fallacy holds, then the importance of the economic vote declines greatly. Why? Because it would suggest that economic evaluation, as expressed by individual citizens, does not ultimately hold the government accountable. A government presiding over bad national economic conditions, such as poor growth or rising unemployment, could escape punishment at the ballot box. Democracy, then, stands badly served. Using a formidable database of European nations, we examine whether national governments, in fact, are punished (or rewarded) by votes on the basis of national economic performance. We look at the general case, voting in normal times, then at voting in times of crisis. Of special interest is the possibility that governments are held still more accountable for the economy during crisis periods.

Below, we look at relevant literature and theory, where we elaborate on the possibilites for the micrological fallacy. That discussion leads to the formulation of two hypotheses for testing, with regard to 
the relationship of macroeconomics and electoral outcomes, one hypothesis for normal times and another for times of crisis. Then we discuss our European data pool and our politico-economic measures, followed by an explication of our methodology. Our estimated equations are presented in three parts: static, dynamic, and crisis. In conclusion, we reconcile the micrological fallacy, and trace a myriad of macroeconomic effects on European electoral outcomes.

\section{LITERATURE AND THEORY}

The scope of the economic voting literature, now estimated at over 500 articles and books, makes its summary difficult (Stegmaier and Lewis-Beck, 2012). However, it can be simplified by focusing theoretically on the classic economic voting paradigm, and substantively on the relevant comparative findings. With respect to theory, the organizing idea is retrospective economic voting, wherein the voter judges the economic record of the government, rewarding or punishing accordingly at the ballot box (Fiorina, 1981; Key, 1966; Lewis-Beck, 1988). With respect to comparative findings, we examine essentially European studies, first at the microlevel, then at the macrolevel. Reviewing the microlevel investigations, where the data are national surveys and the dependent variable is a measure of the incumbent vote, they converge on the notion that sociotropic economic evaluations matter (Anderson, 2000; Duch and Stevenson, 2008; Fernandez-Albertos, 2006; Hellwig, 2008; Lewis-Beck et al., 2008; Nadeau et al., 2013; van der Eijk et al., 2007). When the respondent perceives the economy has worsened over the past year, they are significantly more likely to declare a vote against the government (coalition).

The most recent of these microlevel efforts repeatedly tests the economic voting hypothesis with the largest micro-pool yet (40 surveys from ten European nations - Denmark, France, Germany, Greece, Ireland, Italy, the Netherlands, Portugal, Spain, the United Kingdom). The authors conclude: "the economy is not a mirage. Voters see it, and see it rather clearly.... Economic perceptions, properly understood, have a greater impact than previously imagined." Nadeau et al. (2013: 565). These strong micro-findings contrast to mixed macrolevel findings, from Eastern as well as Western Europe. These aggregate analyses may uncover statistically significant relationships between an objective economic indicator and incumbent vote support, but they can be substantively weak (Bengtsson, 2004; Chappell and Veiga, 2000; Fidrmuc, 2000; Paldam, 1991; Powell and Whitten, 1993; Tufte, 1978). Moreover, there is no agreement on relevant indicators. As Lewis-Beck and Stegmaier (2000: 211) ask, "Which one? ... It could be unemployment, inflation or growth," because the answer varies depending on the study. In summarizing this aggregate work, the far-reaching investigation of Bengtsson (2004: 764) concludes that "One overarching result from this and other studies does, however, seem to be that the fundamental 
economic effects ... are rather weak or non-existent (italics added.)" These spotty results reinforce our fear that the micrological fallacy has been at play, leaving the macrolevel apparently free of any serious economics-elections connection.

The micrological fallacy stands opposite of the ecological fallacy. While both are fallacies of inference, the latter makes the mistake of inferring the part from the whole, e.g., inferring individual economic voting from aggregate patterns connecting macroeconomic indicators and election outcomes. The former, in contrast, makes the mistake of inferring the whole from the part, e.g., inferring an aggregate economics-elections connection from individual patterns of economic voting. In comparative economic voting research, the door stands open to the commitment of a micrological fallacy, given the contradiction between the micro-level, individual survey results and the macro-level, aggregate results. That is, strong micro-findings co-exist with weak to non-existent macro-findings. Two initial micropossibilities might explain this apparent inconsistency First, individual economic perceptions of the national economy could be based on error. Second, these economic perceptions could be accurate, but not add up to the observed macroeconomic condition.

The first possibility was originally posed by Kramer (1983), in his critique of the survey as an instrument for measuring the economy. In particular, he saw sociotropic retrospective items as error-laden, with respondents in the same survey exhibiting widespread disagreement over the condition of the national economy. Part of this error could come from partisan bias for or against the incumbent party (Evans and Andersen, 2006), and another part from general misinformation (Anderson, 2007: 280). Current comparative work suggests that these sources of measurement error do not exercise significant effects, once instrumental variable controls are imposed (Nadeau et al, 2013). But other sources of measurement error could be at work. Much of the survey research bases itself on indirect measures of the vote, e.g., vote intention. It is easy to imagine that vote intention correlates less than perfectly with actual vote. Moreover, it may well correlate with the independent variable of economic perception in biased ways. Further, even assuming vote intention has no systematic measurement error, it usually represents a cross-sectional response in a slice-in-time survey. Therefore, it does not measure a change in vote intention in response to a real change in the economy, as economic voting theory implies.

What about the second possibility, concerning how individual perceptions add up to the objective macro-result? If individual voters perceive the national economy without error, then when those opinions are aggregated they should represent national performance, e.g., if each voter accurately sees positive economic growth, then those perceptions, when aggregated, will show positive economic growth. This inference holds even if, only on average, voters correctly perceive positive economic growth; the assumption here is that the error term in the vote equation lacks correlation with the economic perception 
(Lewis-Beck et al., 2013). However, that error term may be correlated with the $\mathrm{X}$ of economic perception. For example, vote turnout, an omitted variable reflected in the error term, could influence vote choice. A typical case could be when the voter sees a strong economy and so does not bother to vote, since things are going well (Lewis-Beck and Lockerbie, 1989). Under such a scenario, the economic motivation behind the vote would not be accurately reflected in the aggregate electoral outcome. Such a result could help explain rather weak aggregate economic voting results, in the face of apparently strong individual assessments.

The two foregoing individual-level possibilities for inducing a micrological fallacy concern the "part" of the "whole." There is also a third (aggregate-level) possibility, concerning just the "whole" - the measurement of the macroeconomy itself. Obviously, if at the aggregate-level the economy is improperly, or incompletely, measured in a model predicting electoral outcomes, then its effect might not register. As noted, the leading measures have been versions of unemployment, inflation, or growth (at different lags). We would argue that the growth variable stands least likely to feed the micrological fallacy, because of its empirical precision and conceptual breadth. GDP growth, as Norpoth et al. (1991: 5) suggested some time ago, allows us to formulate models with an economic indicator "as global as possible....to capture the shifting weighting scheme utilized in the political economic calculus of the democratic voter." This measurement strategy receives support, in a preliminary way, in the findings of Wilken et al. (1997). Their early cross-sectional examination of 38 world elections (from developed and underdeveloped democracies, 1988-1994) concludes that for "every percentage point of GDP growth in the election year, [the incumbent] party stands to gain 1.4 percent of the vote." (Wilken et al., 1997: 307). Further, more recent economic voting work, by Singer (2011a) and Van der Brug et al. (2007), explicitly supports the use of GDP growth, over inflation and unemployment measures, on grounds that it yields the largest effect.

These foregoing considerations lead us to our first hypothesis:

H1: Positive (negative) GDP growth yields increases (decreases) in incumbent vote support.

We expect $\mathrm{H} 1$ to be supported as a general proposition, when tested against our macro-data-set on European electorates. Such support would be all to the good for, as Paldam (1991: 11) observes: "it is highly desirable if models are general and institution free, so that the same basic model works across countries and over time." After all, the model being tested derives itself from the pure theory of the economic vote. However, as subsequent research has shown, the economic vote, even if a pure force, can be conditioned by institutions and events (Nadeau et al., 2002; Powell and Whitten, 1993). Therefore, we do explore further tests, especially on the clarity of responsibility idea, as shall be seen below. 
Of further interest are the electoral effects of the recent international economic crisis, beginning around 2008. [See, in particular, the respective special symposiums of Escobar-Lemon and Whitten (2011); Lewis-Beck, Costa Lobo, and Bellucci (2012); Lewis-Beck and Whitten (2013)]. With economic policy reform supreme on the agenda of most European governments, we might expect to find there a strengthening of the economic voting effect. If the link between the economy and incumbent vote share becomes more pronounced in times of economic crisis, then the relation between the economy and incumbency voting would be asymmetric. Different strands of evidence can be marshalled for this asymmetry argument. First, voters have sometimes been found to be more responsive to negative economic information, as opposed to positive economic information. Given that people are risk averse, negative messages receive more weight (Lau, 1985). This effect can be further enhanced by negativity bias in the media as well (Soroka, 2006). Second, issues on top of voters' heads are more salient factors determining their vote (Bélanger and Meguid, 2008). For example, Fournier et al. (2003: 57) claim that "issue importance influences the capacity to rate the government's performance: individuals who feel that an issue is important are more likely to evaluate the government on that issue".

More specifically, in times of economic recession, the economy would have more salience to voters. For one, that information on the economy is more easily accessible in times of crisis, according to the work of (Singer, 2011a). Further, Singer (2011b) shows that during an economic recession more citizens perceive the impact of the economy on their personal situation. These findings accord with the earlier European results from Nannestad and Paldam (1997), who showed the presence of a grievance asymmetry at the individual level. Danish voters' evaluations of the economy were stronger predictors of support for government parties when voters perceived a worsening economy, as opposed to an improving economy. However, not all micro-studies support such a result. Lewis-Beck and Stegmaier (2013), in their current review of the problem, conclude that overall micro-level evidence on the asymmetry hypothesis is "mixed." With regard specifically to its presence in times of economic crisis, the debate still continues [for a review there, see Singer, 2011a]. Given the different theoretical arguments (and scattered empirical evidence) for an asymmetric economic vote induced by the condition of crisis itself, we tentatively offer our second hypothesis:

H2: During economic crisis, GDP growth relates more strongly to incumbent vote support.

\section{DATA AND MEASURES}


The dataset covers 359 elections in 31 European countries. While countries outside of Europe are not covered, the focus on this region allows near-exhaustive coverage in a large and balanced national time series pool, from 1950 onwards. Furthermore, recent financial and economic crises warrant a focus on the European context. Several European countries have suffered severely in the post-2008 period, in a pattern of crisis referred to as a "domino effect", because of the interdependence of these economies within the European Union (Bellucci et al., 2012: 469). While the crisis has had an especially profound impact in the European periphery (Lewis-Beck and Nadeau, 2012), overall considerable variation exists in the lived experiences of these European economics (LeDuc and Pammett, 2013). Even though European countries share similarities, their substantial differences remain. This combination of unity and diversity, then, makes Europe an ideal context to test theories of economic voting (LeDuc and Pammet, 2013).

For the measures themselves, country-level data were collected from a number of different sources. The principal dependent variable in the analyses is incumbent vote share. Election results data come from Mackie and Rose (1991), supplemented by election reports in Electoral Studies and the European Journal of Political Research. Additionally on-line sources were consulted for information on the most recent elections (Nordsieck, 2013). Government coalition information comes from the 'Parliament and Government Composition Database, which covers most OECD countries for the post-war period (Döring and Manow, 2011). Incumbent vote shares were then calculated by summing the vote shares of all parties that were in the government coalition before the elections. (To determine what splinter-parties or new parties are to be considered incumbents, we consulted the country-specific information found in election reports in Electoral Studies and the European Journal of Political Research). As can be observed in Figure 1, the distribution of incumbent vote shares in our dataset shows considerable variation, and roughly follows a normal curve (skewness $=0.44$ ).

\section{[FIGURE 1 ABOUT HERE]}

Besides the incumbent vote share, the electoral weight of the incumbent and partisan effects should eventually be controlled for as well. Consequently, in order to develop dynamic models, we make use of the incumbent vote share in the previous election (E-1). For calculating this variable, the same method was applied and the same sources were used as for the construction of the dependent variable, incumbent vote share.

Investigating the effect of the economy on incumbent vote shares, a number of macro-economic indicators can be looked at. As already noted, we focus on the GDP growth rate. An additional advantage of using GDP growth rate as the economic indicator in our analyses is that long-term time series are available for most OECD countries. For the current paper we make use of data on GDP growth rates as 
reported by the Conference Board (2013), which allows us to go back to 1950. Specifically, we measure the GDP growth rate for the year before the election year. This lag structure makes sense, given retrospective theory, which suggests voters evaluate the economy over the past year.

Other variables are also measured. To capture the concept of clarity of responsibility we make use of three different measures. First, the effective number of parties in parliament (Anderson, 2000) is included to take into account the clarity of available alternatives. Therefore, we make use of the LaaksoTaagepera (1979) index, as measured and published by Michael Gallagher (2012). Second, the number of parties in government is measured, using data from the ParlGov database (Döring and Manow, 2011). Third, using the same ParlGov database, we measure the presence of caretaker governments before an election, including a dummy variable where $1=$ the presence of a caretaker government precedes the election, and $0=$ otherwise. (In our "Challenges" section below, we also discuss the measurement of other "test" variables that were introduced).

Testing the second hypothesis, on the effects of economic crisis, requires more than one measure, because "crisis" can be conceptualized in different ways. The first way, popular in the media now, focuses on the economic shifts of the post-2008 period. To assess the effects of this current economic crisis, a crisis-dummy is included, with all elections from $2008=1$, while elections before that $=0$. The second way, which takes a longer view, focuses on theoretical identification and empirical measurement of a year of economic crisis, regardless of where that year may fall along the time spectrum. To assess this sort of crisis, which in principal could occur at any time, we separate out the negative growth figures, labelling them as years of economic crisis. To calibrate the effect of this negative, as compared to positive, economic growth, we model the process via spline regressions. (Descriptive statistics on all variables included in the analysis are listed in Table 1).

\section{[TABLE 1 ABOUT HERE]}

We include the countries in Central and Eastern Europe, as well as those of Western Europe, repeatedly and regularly measured over time. For almost all Western European countries the time series starts in 1950. For Central and Eastern European countries, the data usually begin around the mid-nineties (when they devised functioning competitive elections). These time frames then, correspond to the periods in which democracy was clearly established, a prerequisite for testing our hypotheses. (With respect to Germany, before unification only West Germany is included, but from 1989 onwards the unified country is included. Both are treated as separate countries in the analyses). The full set of countries (31), and elections (359), is quite heterogeneous, as can be observed in the listing of Table 2. 


\section{[TABLE 2 ABOUT HERE]}

\section{METHODS}

The data compose a time-series-cross-section (TSCS), a structure to be taken into account when modeling. Therefore, different approaches were considered. As a baseline, we estimated static models on the effects of different variables on incumbent vote share (without controlling for the previous electoral score of the incumbents). Different modeling strategies were investigated. First, a naïve pooled ordinary least squares model was examined, its standard errors corrected for the country-clusters. Second, a fixed effects (FE) model was developed, in which the country-level effects were simply controlled for by means of country-dummies (Allison, 2009). Third, a random effects generalized least squares (GLS) model was applied, enabling us to fit an estimator that controls for heteroskedasticity and autocorrelation. Fourth, because in general the estimates of a GLS estimation are less efficient, a random coefficient model was estimated by means of a maximum likelihood (ML) procedure as well (Hox, 2010). After static models were explored, dynamic models were developed, with a control on the effect of the electoral result of incumbent parties in the previous election (as a lagged dependent variable - LDV). As with the static models, four approaches were investigated; an OLS pooled model, a fixed effects model, a random effects GLS model and a random effects ML model.

While all the approaches are robust to the basic hypotheses, we favor the fixed effects models (with panel corrected standard errors - PCSE), which we present in Table 3. The estimates of the static model (see Model 1, column 1, Table 3) allow an accounting of non-observed heterogeneity and a treatment for omitted variable bias (via inclusion of country-fixed effects). Additionally, we provide panel corrected standard errors (Beck \& Katz, 1995), which address the heteroskedasticity issue. However, under this modeling specification a problem of significant autocorrelation remains. A traditional test for autocorrelation should not be applied to these pooled time series data. Additionally, the fact that incumbent coalitions differ from election to election renders a Woolridge test for autocorrelation (based on first differenced regression) inappropriate. Therefore, as an alternative we saved the residuals of Model 1, comparing them to the residuals of a model in which both the dependent and the independent variables are lagged one election. These residuals correlate 0.69, making apparent an autocorrelation problem. For this reason we add a lagged dependent variable in Model 2 (see column 2, Table 3). This step renders the model dynamic, changing its interpretation and explicitly taking into account the dependency of incumbent vote support on its previous result. This second model (FE-PCSE-LDV) embodies the specification Beck \& Katz (1995; 2009) recommend for dealing with TSCS data, particularly in this political science context. ${ }^{i}$ 


\section{[TABLE 3 ABOUT HERE]}

\section{MAIN RESULTS}

The analyses presented in Table 3 are encouraging. First, regardless of whether we consider a static or a dynamic model, the fit statistics are strong according to the $\mathrm{R}^{2}$-values. With respect to the independent variable effect, we begin the discussion with Model 1. Looking at the control variables, two attain statistical significance. These results suggest that as the number of parties in government increases, the incumbent vote share increases. Furthermore, the incumbent vote share will tend to be smaller, when the system in general has a larger number of parties. Finally, whether a caretaker government was in office before the election does not significantly affect the incumbent vote share. These structural results are comforting, if unsurprising. What about our main variable of interest, GDP? We observe that it appears to have a statistically significant and substantively important effect. Specifically, a one percentage increase in GDP growth yields about a 0.7 percentage point increase in incumbent support. This is a rather large effect, falling as it does not far from unit elasticity (with its 1:1 percentage ratio).

\section{[TABLE 3 ABOUT HERE]}

The Model 1 results do indicate strong economic effects. It could be argued, however, that in order to investigate the effect of the economy on electoral success and failure, starting points have to be taken into account. More specifically, it may be that current incumbent support partly derives from past incumbent support. At the microlevel, that process would operate through something like the persistence of partisan identification. At the macrolevel, in addition to picking up that pattern, past vote share would tap into independent variables omitted from the model specification (including missing variables on political context or issues, such as immigration or crime). Thus, it acts as a very strong control, increasing predictive power and applying a tough test for the survival of GDP effects. Furthermore, the reported presence of serial autocorrelation in Model 1 argues for the inclusion of a lagged dependent variable. In Model 2, therefore, we take Model 1 a step further, including incumbent vote share in the previous election as an independent variable.

As such, Model 2 incorporates a time component, becoming dynamic and providing further insight into the effect of the economy. According to its estimates (see column 2, Table 3), the effect of the 
GDP growth rate remains significant, even increasing its level (to $\mathrm{p}<.001$ ). Moreover, its strength persists. Indeed, the size of its coefficient is about equal for both modeling approaches (at 0.7). We can say, with more confidence, that the state of the economy affects incumbent support on election day. Further, the explanatory power of Model 2 is considerably higher, with an $\mathrm{R}^{2}$-value indicating that about $80 \%$ of the variance in incumbent vote share is explained. Last, but not least, we can report that building on this specification we tested the possibility of interaction effects relating to the clarity of responsibility hypothesis (Powell and Whitten, 1993); no significant results were found there. ${ }^{\text {ii }}$ These null findings are almost certainly due to the powerful controlling effects of the lagged incumbent vote share variable on the right-hand side, and its capturing of the influence of omitted variables).

\section{CRISIS RESULTS}

Our first hypothesis, on the relationship of GDP growth and incumbent support, receives strong confirmation from the findings in Table 3. What about our second hypothesis, where we expect the economy to relate more strongly to incumbent electoral success during an economic crisis? In order to investigate this possibility different approaches are taken. First, we examine whether the link between the economy and incumbent vote share is more pronounced after the recent economic and financial crisis, begun in 2008. We investigate this by means of a simple crisis-dummy, scored one for elections from 2008 onwards (i.e., 41 out of the 359 elections) and zero otherwise. For testing, we explore the impact of this crisis dummy by itself, and in interaction with the GDP variable. These estimates appear in Table 4. The simple 2008 crisis dummy falls far short of statistical significance in both the static and dynamic models (see, respectively, columns 1 and 3). Further, the interaction crisis term falls far short of significance in the static model, and only achieves marginal significance in the dynamic model. These null, fragile results lead us to the following conclusion: while the incumbent governments of Europe may have been punished by the post-2008 economic crisis, that punishment has been no greater than for economic downturns occurring in other periods. The 2008 economic crisis, then, has not engendered unique effects on incumbent party vote shares of the region.

The fact that the economic blows falling on elected governments after 2008 are not unique does not mean that they were not real blows. But it does mean that another process may be going on. Perhaps economic crisis, rather than being temporally specific, works whenever the economy takes a serious downturn. In other words, the crisis period need not be, in fact should not be, time bound. Thus, we focus on economic downturn in general, by modeling spline regressions. Recall that spline regression has value when the research question concerns what produces differences in slope (Marsh and Cormier, 
2002). Operationalizing zero GDP growth as the turning point (and therefore the spline knot), we can investigate whether the GDP growth effect is more or less pronounced depending if it is positive or negative. Thus, we investigate differences in the size of the effect for negative and positive GDP growth rates, respectively. In order to estimate such a spline regression model, two variables are created. A first variable, called GDP (-) corresponds to GDP growth rates if these are negative, but takes on the value of 0 otherwise. The second variable, called GDP (+) has values corresponding to the GDP growth rates when these are positive, but takes on a value of 0 otherwise. Doing so we use the natural and straightforward zero threshold for investigating asymmetric economic effects first offered by Nannestad and Paldam, 1997).

Applying this spine regression approach, we can observe any differential effects (see columns 2 and 4, Table 4). Are negative GDP growth rates more determining for incumbent vote share? The results of the spline regression models in Table 4 confirm this expectation. In the static, as well as in the dynamic, models both the effects of positive and of negative GDP growth attain significance. Additionally, in the two models, the coefficient for negative economic growth is larger than the coefficient for positive economic growth. Clearly, the results are robust and straightforward: negative economic growth has more importance for incumbent electoral results. While the coefficients differ depending on the specific model, the negative spline coefficient approaches twice the magnitude of the positive spline coefficient (respectively, .99/.63 and 1.00/.66). These findings suggest that the effect of the economy, looked upon from a macro-perspective, almost doubles in times of economic recession, compared to times of economic growth. Both coefficients are positive, indicating that as the economy is doing better, incumbents obtain a larger share of the votes. For example, moving from a $-2 \%$ to a $-1 \%$ GDP growth rate has close to twice the effect on incumbent support, compared to moving from $1 \%$ to $2 \%$ GDP growth rate. Clearly, economic crisis, understood as the general phenomenon of negative economic growth, intensifies the impact of GDP change on incumbent vote, so supporting our second hypothesis.

\section{CHALLENGES}

Thus far, we have found strong support for our two central hypotheses, in terms of the functioning of these European democracies. First, in general, economic growth relates to incumbent vote support as expected. In particular, negative economic growth generally yields decreases in incumbent vote support. Second, the relationship between economic growth and incumbent vote support strengthens under economic crisis. In particular, it takes an asymmetric form, with negative economic growth having a greater impact than positive economic growth. As firm as these findings appear to be, they are not immune 
from challenge. In this section, we consider several relevant challenges, from the measurement of the dependent variable of incumbent vote and the independent variable of economic performance, to the specification of the non-economic independent variables. Below, we consider these in turn, beginning with the measurement questions, and ending with the specification questions.

Initially, we face the question of whether the dependent variable should be incumbent coalition votes (as it is now), or (the more restricted) prime minister party votes. The latter has been argued by some to be relatively more affected by economic outcomes (see Anderson, 2000; Duch and Stevenson, 2008). To test this possibility, we simply substituted prime minister party vote share for the dependent variable (and the lagged dependent variable on the right-hand side) in the basic dynamic Model 2 of Table 3. Contrary to rival argument, the general effect of the economy now appears halved (i.e., a GDP growth coefficient of only .39, compared to its Table 3 value of .74). ${ }^{\text {iii }}$ Additionally, our hypothesis of asymmetrical economic effects fails of support, when the dependent variable is prime minister party support. At least two reasons for these weaker findings present themselves. First, while the distribution of vote share of the incumbent coalition approximates normality, the distribution of prime minister vote share variable is noticeably skewed. Second, while ruling coalitions generally have a combined vote share close to $50 \%$ across these countries, the electoral strength of the prime minister's party varies much more, according to country- and electoral-system-specific characteristics. This fact renders the pooled approach a more blunt instrument of analysis. Clearly, given the distributional complexities embedded in this large TSCS data-set, our more global dependent variable measure of incumbency support appears preferred.

With respect to the key independent variable - the economy - we have relied on our GDP measure. But we might reasonably ask what would happen if a leading rival indicator - the unemployment rate - were used? Therefore, we perform the main analyses with change in unemployment rates instead of GDP growth as the economic variable. It is operationalized as the difference between the unemployment rate one year before the election year, and the unemployment rate two years before the election year. The necessary data, from the IMF World Economic Outlook Database (2013), make for smaller sample, only covering elections from 1980. Still, the results are suggestive. First, in an estimation comparable to that of Model 2 (Table 3), where unemployment is substituted for GDP, one observes that rising unemployment rates significantly harm incumbent vote share, as expected. Additionally, replicating the crisis analysis of Model 2 (Table 4) with the substitution of the unemployment variables suggests similar asymmetrical effects. As expected, increasing unemployment (hinting at a deteriorating economy) has a more profound effect on incumbent vote share, compared to decreasing unemployment (hinting at a growing economy). ${ }^{\text {iv }}$ We can therefore conclude that the findings of an asymmetrical economic effect presented in the manuscript are not likely driven by specificities of the GDP growth-indicator. Hence, we continue to favor 
the GDP measure over this unemployment measure. In addition to the theoretical and empirical reasons already advanced, using the unemployment measures gives an available sample size of just 181, about half that of Table 3. Moreover, in part because of this smaller sample, the statistical significance levels are not nearly as impressive.

Beyond the above considerations of measurement of the key dependent and independent variables, there could be concern over whether more predictor variables should be added to the specification. On that issue, it is important to first recall that the dynamic model contains a lagged dependent variable on the right-hand side of the equation (LDV). Fortunately, the presence of this LDV also acts as a control on omitted variables (assuming they also operate at $\mathrm{t}-1$ ). While this makes for considerable confidence in the desirable statistical properties of the GDP coefficients, attention to other available independent variables still has merit. There are two in particular: globalization and democratic history. Take the former first. The process of globalization has been important over the period covered (1950-2013). We especially want to know whether, in accounting for globalization, economic growth still functions asymmetrically under crisis. Therefore, we investigate the main and interaction effects of globalization, as measured by trade openness, adding it to the specification (of the dynamic FE PCSE LDV model of Table 4, column 4). Following Fernandez-Albertos (2006), we use as a measure the sum of imports and exports of a country divided by GDP. Data were obtained from the World Bank database and are available only from 1960 onwards, so yielding a somewhat smaller sample size (The World Bank 2013a; 2013b).. Looking at the results, in Table 5 (column 1), we observe that trade openness has neither statistically significant main or interaction effects. Hence, globalization, as measured by trade openness, does not seem to alter the reported asymmetrical effects of GDP growth rates. (Furthermore, these spline regression effects from GDP sustain their significance, with negative growth continuing to exercise about twice the effect of positive growth).

\section{[TABLE 5 ABOUT HERE]}

Take the second specification concern raised, regarding the different democratic histories of these nations, most notably those who were formerly communist systems. Rather than simply including a postcommunist dummy in the analyses, we offer a more general operationalization of experience with electoral democracy. We add to our key model the 'years of stable democracy,' a variable which we created by means of information from the Polity IV dataset (Marshall and Gurr, 2012). We present the 
results in Table 5 (column 2). The main effect of years of democracy is negative and significant, indicating that as countries have more experience with electoral democracy, incumbents tend to obtain a smaller vote share. However, the interactions of years of democracy with negative and positive GDP growth are not significant, indicating that the different electoral histories for democracy do not affect the mechanism of economic voting in the region. This conclusion receives reinforcement by observing that the two key coefficients, for negative GDP growth and positive GDP growth, are very close in magnitude to their original values in the key model of Table 4 (column 2).

Besides the question of differing democratic histories, the question arises of different levels of economic development, which might bias growth effects on incumbent support. For example, would a percentage point of economic growth in the United Kingdom (a developed industrial economy) have the same effect on incumbent support as a percentage point of economic growth in Romania (a postcommunist developing economy)? Given the economic heterogeneity of this national pool, we should address the matter. An especially efficient way to do so involves the use of random effects estimation instead of a fixed effects model. That is, rather than controlling away the variance at the country-level via country-dummies (as done with a fixed effects model), we explicitly investigate this variance (Hox, 2010). Such a random coefficient ML estimation procedure allows the investigation of varying intercepts between countries, but also of random slopes. To see whether there is variation between countries in the effect of a specific variable - here GDP growth - one examines these random slopes.

In Table 6 we present the results of random effects MLE models (using the specification of Table 4, column 2). The first equation offers the base model, where random country-intercepts are specified; in the second equation we also assess any significant country-level variance in the effect of GDP growth. A number of conclusions can be drawn. First, the earlier findings in the manuscript are robust to a random effects ML specification, where we observe again an asymmetrical effect of economic voting on the incumbent vote share. Second, a significant and substantial amount of variance in incumbent vote share exists at the country level. Third, and most pointedly, we do not observe significant country-level variation in the effect of GDP growth on incumbent vote share (as shown in the $\sigma^{2}$-values at the bottom of the table). The economic development level, country-to-country, does not significantly impact the economic voting coefficient. In addition to making this clear, the result supports our more direct fixed effects approach (of the earlier tables).

[TABLE 6 ABOUT HERE]

\section{CONCLUSION}


Economic voting seems undeniable, according to the numerous micro-level, election survey studies undertaken around the democratic world. These results refute the charge of an ecological fallacy, with respect to the inference that economic perceptions influence vote choice. However, economic voting theory has another charge to overcome, that of commiting a micrological fallacy. We have argued the plausiblity of the notion that, while individual citizens may be economic voters, the entire electorate itself may not act like an economic voter. In other words, those individual economic vote choices might not add up to a macroeconomic impact on the incumbent government's vote share. This possibility we base not only on logic, but on the weak empirical results from numerous aggregate investigations, which have attempted to link macroeconomic fluctuations to overall electoral outcomes.

Herein, we attempt to show a micrological fallacy has not been committed, by demonstrating an unambigous connection between GDP growth and aggregate incumbent vote share in European democratic elections. We explore a very large pool of elections (359) from many countries (31) over an extended time period (1950-2013). While the countries confine themselves to the European continent, they nevertheless represent considerable political and economic heterogeneity. Our analyses, and their various challenges, reveal sharp and powerful effects. In general, a one percentage point change in economic growth produces almost a three-quarter percentage point change in incumbent vote support. This clear confirmation of our first hypothesis has merit in its own right. However, it has a double importance, by its refutation of the micrological fallacy. That macro-refutation of the micrological fallacy, along with the micro-refutation of the ecological fallacy, make for a perfect marriage. With unparalleled confidence, we can assert that economic voting is real, and really matters.

.This confidence allowed us to pursue our second hypothesis with vigor. Economic crisis alters the impact of growth on the vote, rendering it asymmetric. Economic crisis, defined as negative GDP growth, can occur anywhere along the time line. And, when these bad economic times occur, its electoral impact is magnified, compared to economic good times. Specifically, the cost in incumbent votes from an economic bust (e.g., a negative growth of $-1 \%$ ) comes to about double the benefit in incumbent votes received from an economic boom (e.g., a positive growth of $+1 \%$ ). Thus, we see that governments are punished more for bad economic policy, than they are rewarded for good economic policy. Perhaps that is as it should be, for it pushes governments to work harder at reducing mass hardship. Further, this asymmetry in reward and punishment suggests that leaders are held especially accountable for poor performance. If so, it serves as a useful reminder to elected officials that the people are paying attention.

\section{REFERENCES}


Adolph, C., Butler, D. M. and Wilson, S. E, (2005) Like shoes and shirt, one size does not fit all: Evidence on time series cross-section estimators and specifications from Monte Carlo experiments. Paper presented at the $101^{\text {st }}$ Annual Conference of the American Political Science Association; 31 August3 September, Washington DC, United States.

Allison, P. D. (2009) Fixed Effects Regression Models. Los Angeles: Sage.

Anderson, C. J. (2000) Economic voting and political context : A comparative perspective. Electoral Studies 19(2/3): 151-170.

Anderson, C. J. (2007) The end of economic voting? Contingency dilemmas and the limits of democratic accountability. Annual Review of Political Science 10: 271-296.

Beck, N. and Katz, J. N. (1995) What to do (and not to do) with time-series cross-section data. American Political Science Review 89(3): 634-647.

Beck, N. and Katz, J. N. (2009) Modeling Dynamics in Time-Series-Cross-Section Political Economy Data. Pasadena (CA): Division of the Humanities and Social Sciences, California Institute of Technology. Social Science Working paper 1304.

Bélanger, E. and Meguid, B. (2008) Issue salience, issue ownership, and issue-based vote choice. Electoral Studies 27(3): 477-491.

Bengtsson, A. (2004) Economic voting: The effect of political context, volatility and turnout on voters' assignment of responsibility. European Journal of Political Research 43(5): 749-767.

Blackburn, S. (2008) Oxford Dictionary of Philosophy. Oxford: Oxford University Press.

Borre, O. (1997) Economic voting in Danish electoral surveys 1987-1994. Scandinavian Political Studies 20(4): 347-365.

Campbell, A., Converse, P., Miller, W. and Stokes, D. (1960) The American Voter. Chicago: The University of Chicago Press.

Chappell, H. W. J. and Veiga, L. G. (2000) Economics and elections in Western Europe: 1960-1997. Electoral Studies 19(2-3): 183-197.

Döring, H. and Manow, P. (2011) Parliament and government composition database (ParlGov): An infrastructure for empirical information on parties, elections and governments in modern democracies.

Duch, R. M. (2007) Comparative studies of the economy and the vote. In: C. Boix and S. Stokes (eds.) Encyclopedia of Comparative Politics. Oxford: Oxford University Press.

Duch, R. M. and Stevenson, R. T. (2008) The economic vote: How political and economic institutions condition election results. New York: Cambridge University Press.

Escobar-Lemmon, M. and Whitten, G. (2011) Special symposium on the politics of economic crisis. Electoral Studies 30(3):387-594. 
Evans, G. and Andersen, R. (2006) The political conditioning of economic perceptions. Journal of Politics 68(1): 194-207.

Fernandez-Albertos, J. (2006) Does internationalisation blur responsibility? Economic voting and economic openness in 15 European countries. West European Politics 29(1):28-46.

Fidrmuc, J. (2000) Economics of voting in post-communist countries. Electoral Studies 19(2-3): 199-217.

Fiorina, M. P. (1981) Retrospective Voting in American National Elections. New Haven: Yale University Press.

Fournier, P., Blais, A., Nadeau, R., Gidengil, E. and Nevitte, N. (2003) Issue importance and performance voting. Political Behavior 25(1): 51-67.

Gallagher, M. (2012) Electoral systems website, http://www.tcd.ie/Political_Science/staff/michael_gallagher/ElSystems/, accessed August 2013.

Hellwig, T. (2008) Globalization, policy constraints and vote choice. The Journal of Politics 70(4): 11281141.

Hellwig, T. (2010) Context, information, and performance voting. In: R.J. Dalton and C.J. Anderson (eds.) Citizens, Context, and Choice: How Context Shapes Citizens' Electoral Choices. Oxford: Oxford University Press, pp. 149-175.

Hox, J. J. (2010) Multilevel Analysis. Techniques and Applications. New York: Routledge.

IMF (2013). World Economic Outlook Database, April 2013, www.imf.org/external/pubs/ft/weo/2013/01/weodata/download.aspx, accessed August 2013.

Judson, K. A. and Owen, A. L. (1999) Estimating dynamic panel data models: A guide for macroeconomics. Economic Letters 65: 9-15.

Key, V. O. J. (1966) The Responsible Electorate: Rationality in Presidential Voting 1936-1960. Cambridge: Harvard University Press.

Kiewiet, D. R. (1983) Macroeconomics and Micropolitics: The Electoral Effects of Economic Issues. Chicago: University of Chicago Press.

Kramer, G. (1983) The ecological fallacy revisited: Aggregate-versus individual-level findings on economics and elections, and sociotropic voting. American Political Science Review 77: 92-111.

Laakso, M. and Taagepera, R. (1979) The "Effective" Number of parties: A measure with application to west Europe. Comparative Political Studies 12(1): 3-27.

Lau, R. R. (1985) Two explanations for negativity effects in political behavior. American Journal of Political Science 29(1): 119-138.

LeDuc, L. and Pammett, J. H. (2013) The fate of governing parties in times of economic crisis. Electoral Studies 32(3): 494-499. 
Lewis-Beck, M. S. (1983) Economics and the French voter: A microanalysis. Public Opinion Quarterly 47(3): 347-360.

Lewis-Beck, M. S. (1988) Economics and Elections. The Major Western Democracies. Ann Arbor: The University of Michigan Press.

Lewis-Beck, M. S., Costa Lobo, M. and Bellucci, P. (2012) Special symposium: Economic crisis and elections: The European periphery. Electoral Studies 31(3): 469-642.

Lewis-Beck, M. S., Jacoby, W. G., Norpoth, H. and Weisberg, H. F. (2008) The American Voter Revisited. Ann Arbor: University of Michigan Press.

Lewis-Beck M. S. and Lockerbie, B. (1989) Economics, votes, protests: Western European cases. Comparative Political Studies 22(2): 155-177.

Lewis-Beck, M. S. and Nadeau, R. (2012) PIGS or not? Economic voting in Southern Europe. Electoral Studies 31(3): 472-477.

Lewis-Beck, M. S. and Stegmaier, M. (2000) Economic determinants of electoral outcomes. Annual Review of Political Sciences 3(1): 183-219.

Lewis-Beck, M. S. and Stegmaier, M. (2007) Economic models of voting. In: R.J. Dalton and H.-D. Klingeman (eds.) The Oxford Handbook of Political Behavior. Oxford: Oxford University Press, pp. 518-537.

Lewis-Beck, M. S., Martini, N. F. and Kiewiet, D. R. (2013) The nature of economic perceptions in mass publics. Electoral Studies 32(3): 524-528.

Lewis-Beck, M. S. and Whitten, G. D. (2013). Special symposium. Economics and elections: Effects deep and wide. Electoral Studies 32(3): 391-562.

Mackie, T. T. and Rose, R. (1991) The International Almanac of Electoral History. London: MacMillan.

Marsh, L. C. and Cormier, D. R. (2002) Spline Regression Models. Thousand Oaks: Sage.

Marshall, M. G. and Gurr, T. R. (2012) Polity IV Project: Political Regime Characteristics and Transitions, 1800-2012, www.systemicpeace.org/polity/polity4.htm, accessed August 2013.

Nadeau, R., Lewis-Beck, M. S. and Bélanger, E. (2013) Economics and elections revisited. Comparative Political Studies 46(5): 551-573.

Nadeau, R., Niemi, R. G. and Yoshinaka, A. (2002) A cross-national analysis of economic voting: Taking account of the political contexts across time and nations. Electoral Studies 21(3): 403-423.

Nannestad, P. and Paldam, M. (1994) The VP function: A survey of the literature on vote and popularity functions after 25 years. Public Choice 79(3-4):213-245.

Nannestad, P. and Paldam, M. (1997) The grievance asymmetry revisited: A micro study of economic voting in Denmark, 1986-1992. European Journal of Political Economy 13(1): 81-99. 
Nordsieck, W. (2013). Parties and Elections in Europe, www.parties-and-elections.eu, accessed August 2013.

Norpoth, H. (1996) The economy. In: L. Leduc, R.G. Niemi and P. Norris (eds.) Comparing Democracies: Elections and Voting in Global Perspective. Thousand Oaks: Sage, pp. 299-318.

Norpoth, H., Lewis-Beck, M. S. and Lafay, J. D. (1991) Economics and Politics: The Calculus of Support. Ann Arbor: University of Michigan Press.

Pacek, A. C. and Radcliff, B. (1995) Economic voting and the welfare state: A cross-national analysis. The Journal of Politics 57(1): 44-61.

Paldam, M. (1991) How robust is the vote function? A study of seventeen nations over four decades. In: H. Norpoth, M. S. Lewis-Beck and J. D. Lafay (eds.) Economics and Politics: The Calculus of Support. Ann Arbor: University of Michigan Press, pp. 9-31.

Powell, G. B. and Whitten, G. D. (1993) A cross-national analysis of economic voting: Taking account of the political context. American Journal of Political Science 37(2):391-414.

Robinson, W. S. (1950) Ecological correlation and the behavior of individuals. American Sociological Review 15: 351-357.

Sanders, D. (2003) Party identification, economic perceptions, and voting in British general elections, 1974-1997. Electoral Studies 22(2):239-263.

Singer, M. (2011b) When do voters actually think "It's the economy"? Evidence from the 2008 presidential campaign. Electoral Studies 30(4): 621-632.

Singer, M. (2011a) Who says "It's the economy"? Cross-national and cross-individual variation in the salience of economic performance. Comparative Political Studies 44(3):284-312.

Soroka, S. N. (2006) Good news and bad news: Asymmetric responses to economic information. The Journal of Politics 68(2): 372-385.

Stegmaier, M. and Lewis-Beck, M. S. (2013). Economic Voting. In: R. Valelly (ed.) Oxford Bibliographies in Political Science. New York: Oxford University Press, forthcoming.

The Conference Board (2013). Total Economy Database: Real Gross Domestic Product, www.conferenceboard.org/data/economydatabase, accessed August 2013.

The World Bank (2013a). Data: Imports of Goods and Services (\% of GDP), data.worldbank.org/indicator/NE.IMP.GNFS.ZS, accessed August 2013.

The World Bank (2013b). Data: Exports of Goods and Services (\% of GDP), data.worldbank.org/indicator/NE.EXP.GNFS.ZS, accessed August 2013.

Tufte, E. R. (1978) Political Control of the Economy. Princeton: Princeton University Press. van der Brug, W., van der Eijk, C. and Franklin, M. (2007) The Economy and the Vote: Economic Conditions and Elections in Fifteen Countries. New York: Cambridge University Press. 
van der Eijk, C., Franklin, M., Demant, F. and van der Brug, W. (2007) The endogenous economy: 'real' economic conditions, subjective economic evaluations and government support. Acta Politica 42(1): 1-22.

Wilken, S., Haller, B. and Norpoth, H. (1997) From Argentina to Zambia: A world-wide test of economic voting. Electoral Studies 16(3): 301-316. 
TAB LE 1. Descriptive statistics of variables in the analyses

\begin{tabular}{lccccc}
\hline & N & Mean & Std. Dev. & Min. & Max. \\
\hline Incumbent vote share & 359 & 45.72 & 15.79 & 5.60 & 96.80 \\
Incumbent vote share (E-1) & 359 & 50.36 & 14.03 & 10.20 & 97.90 \\
GDP growth rate & 359 & 3.27 & 3.41 & -12.84 & 20.81 \\
GDP growth rate (-) & 359 & -.30 & 1.29 & -12.84 & 0.00 \\
GDP growth (+) & 359 & 3.57 & 2.80 & 0.00 & 20.81 \\
Caretaker government & 359 & 0.09 & 0.29 & 0 & 1 \\
ENEP & 359 & 4.47 & 1.70 & 1.70 & 13.82 \\
Number of parties in & 359 & 2.20 & 1.15 & 1 & 6 \\
government & & & & & \\
Crisis (2008 onwards) & 359 & 0.11 & 0.32 & 0 & 1 \\
\hline
\end{tabular}


TAB LE 2. Cases included in the analyses

\begin{tabular}{|c|c|c|c|}
\hline Country & $\#$ & $\%$ & Period \\
\hline Austria & 18 & 5.01 & $1953-2008$ \\
\hline Belgium & 18 & 5.01 & $1954-2010$ \\
\hline Britain & 15 & 4.18 & $1955-2010$ \\
\hline Bulgaria & 5 & 1.39 & 1994-2009 \\
\hline Cyprus & 7 & 1.95 & 1981-2011 \\
\hline Czech Republic & 5 & 1.39 & 1996-2010 \\
\hline Denmark & 23 & 6.41 & $1953-2011$ \\
\hline Estonia & 5 & 1.39 & $1995-2011$ \\
\hline Finland & 16 & 4.46 & 1954-2011 \\
\hline France & 15 & 4.18 & $1956-2012$ \\
\hline Germany & 5 & 1.39 & 1994-2009 \\
\hline Greece & 14 & 3.90 & $1977-2012$ \\
\hline Hungary & 5 & 1.39 & 1994-2010 \\
\hline Iceland & 19 & 5.29 & 1953-2013 \\
\hline Ireland & 17 & 4.74 & 1953-2011 \\
\hline Italy & 16 & 4.46 & 1953-2013 \\
\hline Latvia & 5 & 1.39 & 1995-2011 \\
\hline Lithuania & 5 & 1.39 & 1996-2012 \\
\hline Luxembourg & 12 & 3.34 & 1954-2009 \\
\hline Malta & 10 & 2.79 & $1966-2008$ \\
\hline Netherlands & 19 & 5.29 & $1952-2012$ \\
\hline Norway & 15 & 4.18 & 1953-2009 \\
\hline Poland & 6 & 1.67 & 1993-2011 \\
\hline Portugal & 11 & 3.06 & 1980-2011 \\
\hline Romania & 6 & 1.67 & 1992-2012 \\
\hline Slovak Republic & 6 & 1.67 & 1994-2012 \\
\hline Slovenia & 6 & 1.67 & 1992-2011 \\
\hline Spain & 10 & 2.79 & 1979-2011 \\
\hline Sweden & 19 & 5.29 & $1952-2010$ \\
\hline Switzerland & 15 & 4.18 & 1955-2011 \\
\hline West Germany & 11 & 3.06 & 1953-1990 \\
\hline Total & 359 & 100.00 & $1952-2013$ \\
\hline
\end{tabular}


TAB LE 3. Effect of the economy on incumbent vote shares

\begin{tabular}{lcc}
\hline & Model 1: Static & Model 2: Dynamic \\
& FE PCSE & FE PCSE LDV \\
\hline Incumbent vote share (e-1) & $0.844 * * *$ \\
& & $(0.043)$ \\
GDP growth & $0.713 * *$ & $0.737 * * *$ \\
& $(0.214)$ & $(0.146)$ \\
Caretaker government & 3.190 & 2.136 \\
& $(2.670)$ & $(1.519)$ \\
ENEP (e-1) & $-2.614 * * *$ & 0.780 \\
& $(0.493)$ & $(0.438)$ \\
Number of parties in government & $7.009 * * *$ & 0.347 \\
& $(1.013)$ & $(0.576)$ \\
Constant & $56.629 * * *$ & 2.730 \\
& $(4.937)$ & $(3.318)$ \\
Country FE & Yes & Yes \\
$\mathrm{N}_{\text {elections }}$ & 359 & 359 \\
$\mathrm{~N}_{\text {countries }}$ & 31 & 31 \\
$\mathrm{R}^{2}$ & 0.611 & 0.809 \\
\hline Sign: $* \mathrm{p}<0.05 ; * * \mathrm{p}<0.01 ; * * * \mathrm{p}<0.001$ (two-tailed test). Panel corrected standard errors reported.
\end{tabular}


TAB LE 4. Cris is effects

\begin{tabular}{|c|c|c|c|c|}
\hline & \multicolumn{2}{|c|}{$\begin{array}{c}\text { Model 1: Static } \\
\text { FE PCSE }\end{array}$} & \multicolumn{2}{|c|}{$\begin{array}{l}\text { Model 2: Dynamic } \\
\text { FE PCSE LDV }\end{array}$} \\
\hline & $\begin{array}{l}\text { Interaction } \\
\text { Crisis*GDP }\end{array}$ & $\begin{array}{l}\text { Splines } \\
\text { regression }\end{array}$ & $\begin{array}{l}\text { Interaction } \\
\text { Crisis*GDP }\end{array}$ & $\begin{array}{l}\text { Splines } \\
\text { regression }\end{array}$ \\
\hline Incumbent vote share (e-1) & & & $\begin{array}{c}0.845^{* * * *} \\
(0.041)\end{array}$ & $\begin{array}{c}0.844 * * * \\
(0.043)\end{array}$ \\
\hline GDP growth & $\begin{array}{l}0.575^{*} \\
(0.244)\end{array}$ & & $\begin{array}{c}0.601 * * * \\
(0.143)\end{array}$ & \\
\hline Negative GDP growth & & $\begin{array}{l}0.988^{*} \\
(0.474)\end{array}$ & & $\begin{array}{l}1.001 * * \\
(0.387)\end{array}$ \\
\hline Positive GDP growth & & $\begin{array}{l}0.631^{*} \\
(0.267)\end{array}$ & & $\begin{array}{c}0.657 * * * \\
(0.146)\end{array}$ \\
\hline Post-2008 crisis & $\begin{array}{l}-3.668 \\
(2.219)\end{array}$ & & $\begin{array}{l}-1.951 \\
(1.576)\end{array}$ & \\
\hline Post-2008 crisis*GDP growth & $\begin{array}{c}0.322 \\
(0.303)\end{array}$ & & $\begin{array}{l}0.675^{*} \\
(0.319)\end{array}$ & \\
\hline Caretaker government & $\begin{array}{c}3.442 \\
(2.646)\end{array}$ & $\begin{array}{c}3.434 \\
(2.731)\end{array}$ & $\begin{array}{c}2.448 \\
(1.486)\end{array}$ & $\begin{array}{c}2.370 \\
(1.528)\end{array}$ \\
\hline $\operatorname{ENEP}(\mathrm{e}-1)$ & $\begin{array}{l}-2.640 * * * \\
(0.494)\end{array}$ & $\begin{array}{l}-2.627 * * * \\
(0.504)\end{array}$ & $\begin{array}{c}0.810 \\
(0.426)\end{array}$ & $\begin{array}{c}0.768 \\
(0.449)\end{array}$ \\
\hline $\begin{array}{l}\text { Number of parties in } \\
\text { government }\end{array}$ & $\begin{array}{l}7.132 * * * \\
(1.019)\end{array}$ & $\begin{array}{c}7.032 * * * \\
(1.028)\end{array}$ & $\begin{array}{c}0.355 \\
(0.543)\end{array}$ & $\begin{array}{c}0.370 \\
(0.596)\end{array}$ \\
\hline Constant & $\begin{array}{l}57.103 * * * \\
(5.048)\end{array}$ & $\begin{array}{l}56.916^{* * * *} \\
(5.036)\end{array}$ & $\begin{array}{c}3.001 \\
(3.316)\end{array}$ & $\begin{array}{l}3.010 \\
(3.394)\end{array}$ \\
\hline $\begin{array}{l}\text { Country FE } \\
\mathrm{N}_{\text {elections }} \\
\mathrm{N}_{\text {countries }} \\
\mathrm{R}^{2}\end{array}$ & $\begin{array}{c}\text { Yes } \\
359 \\
31 \\
0.615\end{array}$ & $\begin{array}{c}\text { Yes } \\
359 \\
31 \\
0.611\end{array}$ & $\begin{array}{c}\text { Yes } \\
359 \\
31 \\
0.812\end{array}$ & $\begin{array}{c}\text { Yes } \\
359 \\
31 \\
0.810\end{array}$ \\
\hline
\end{tabular}

Sign: * $\mathrm{p}<0.05 ; * * \mathrm{p}<0.01 ; * * * \mathrm{p}<0.001$ (two-tailed test). Panel corrected standard errors reported. 
TAB LE 5. The mediating effect of trade openness and years of democratic stability on the effect of GDP on the incumbent vote share

\begin{tabular}{|c|c|c|}
\hline & $\begin{array}{l}\text { Model 1: Dynamic } \\
\text { FE PCSE LDV }\end{array}$ & $\begin{array}{l}\text { Model 2: Dynamic } \\
\text { FE PCSE LDV }\end{array}$ \\
\hline Incumbent vote share $(\mathrm{e}-1)$ & $\begin{array}{c}0.780 * * * \\
(0.057)\end{array}$ & $\begin{array}{c}0.831 * * * \\
(0.048)\end{array}$ \\
\hline Negative GDP growth & $\begin{array}{l}2.306^{*} \\
(1.061)\end{array}$ & $\begin{array}{l}0.925^{*} \\
(0.425)\end{array}$ \\
\hline Positive GDP growth & $\begin{array}{l}1.101 * * \\
(0.408)\end{array}$ & $\begin{array}{l}0.563^{*} \\
(0.249)\end{array}$ \\
\hline Trade openness & $\begin{array}{l}-0.030 \\
(0.048)\end{array}$ & \\
\hline $\begin{array}{l}\text { Trade openness*Negative GDP } \\
\text { growth }\end{array}$ & $\begin{array}{l}-0.031 \\
(0.023)\end{array}$ & \\
\hline $\begin{array}{l}\text { Trade openness*Positive GDP } \\
\text { growth }\end{array}$ & $\begin{array}{l}-0.009 \\
(0.007)\end{array}$ & \\
\hline Years of stable democracy & & $\begin{array}{c}-0.096 * * * \\
(0.028)\end{array}$ \\
\hline Years of stable democracy* & & 0.003 \\
\hline Negative GDP growth & & $(0.006)$ \\
\hline Years of stable democracy* & & -0.004 \\
\hline Positive GDP growth & & $(0.004)$ \\
\hline Caretaker government & $\begin{array}{c}2.693 \\
(1.870)\end{array}$ & $\begin{array}{l}1.600 \\
(1.604)\end{array}$ \\
\hline $\operatorname{ENEP}(\mathrm{e}-1)$ & $\begin{array}{l}0.875 \\
(0.449)\end{array}$ & $\begin{array}{l}1.079 * \\
(0.435)\end{array}$ \\
\hline Number of parties in government & $\begin{array}{l}0.453 \\
(0.684)\end{array}$ & $\begin{array}{c}0.590 \\
(0.603)\end{array}$ \\
\hline Constant & $\begin{array}{l}5.887 \\
(4.661)\end{array}$ & $\begin{array}{l}6.681 \\
(3.517)\end{array}$ \\
\hline Country FE & Yes & Yes \\
\hline $\mathrm{N}_{\text {elections }}$ & 331 & 359 \\
\hline $\mathrm{N}_{\text {countries }}$ & 31 & 31 \\
\hline $\mathrm{R}^{2}$ & 0.773 & 0.819 \\
\hline
\end{tabular}


TAB LE 6. Random slope of GDP growth

\begin{tabular}{|c|c|c|}
\hline & $\begin{array}{l}\text { Model 1: Dynamic } \\
\text { Random effects } M L\end{array}$ & $\begin{array}{l}\text { Model 2: Dynamic } \\
\text { Random effects } M L\end{array}$ \\
\hline Incumbent vote share $(\mathrm{e}-1)$ & $\begin{array}{c}0.849 * * * \\
(0.044)\end{array}$ & $\begin{array}{c}0.855^{* * * *} \\
(0.044)\end{array}$ \\
\hline Negative GDP growth & $\begin{array}{c}1.159 * * * \\
(0.347)\end{array}$ & $\begin{array}{l}1.189 * \\
(0.481)\end{array}$ \\
\hline Positive GDP growth & $\begin{array}{c}0.572 * * * \\
(0.158)\end{array}$ & $\begin{array}{c}0.594 * * * \\
(0.173)\end{array}$ \\
\hline Caretaker government & $\begin{array}{l}1.683 \\
(1.527)\end{array}$ & $\begin{array}{c}2.723 \\
(1.559)\end{array}$ \\
\hline $\operatorname{ENEP}(\mathrm{e}-1)$ & $\begin{array}{c}0.253 \\
(0.386)\end{array}$ & $\begin{array}{c}0.280 \\
(0.386)\end{array}$ \\
\hline Number of parties in government & $\begin{array}{c}0.697 \\
(0.622)\end{array}$ & $\begin{array}{c}0.585 \\
(0.623)\end{array}$ \\
\hline Constant & $\begin{array}{l}-2.770 \\
(2.929) \\
\end{array}$ & $\begin{array}{l}-3.049 \\
(2.930) \\
\end{array}$ \\
\hline$\sigma_{\text {countries }}^{2}$ & $\begin{array}{c}26.135^{* *} \\
(9.527)\end{array}$ & $\begin{array}{l}26.726^{* *} \\
(10.571)\end{array}$ \\
\hline$\sigma^{2}$ negative GDP growth & & $\begin{array}{c}0.983 \\
(1.220)\end{array}$ \\
\hline$\sigma_{\text {positive GDP growth }}^{2}$ & & $\begin{array}{c}0.104 \\
(0.215)\end{array}$ \\
\hline $\mathrm{N}_{\text {elections }}$ & 359 & 359 \\
\hline $\mathrm{N}_{\text {countries }}$ & 31 & 31 \\
\hline Rho & 0.332 & 0.356 \\
\hline $\mathrm{LL}_{\text {intercept }}$ & -1532.7302 & -1532.7302 \\
\hline $\mathrm{LL}_{\text {full model }}$ & -1248.7998 & -1247.7375 \\
\hline
\end{tabular}

Sign: $* \mathrm{p}<0.05 ; * * \mathrm{p}<0.01 ; * * * \mathrm{p}<0.001$ (two-tailed test). 
Figure 1. Dependent variable: incumbent vote share (\%)

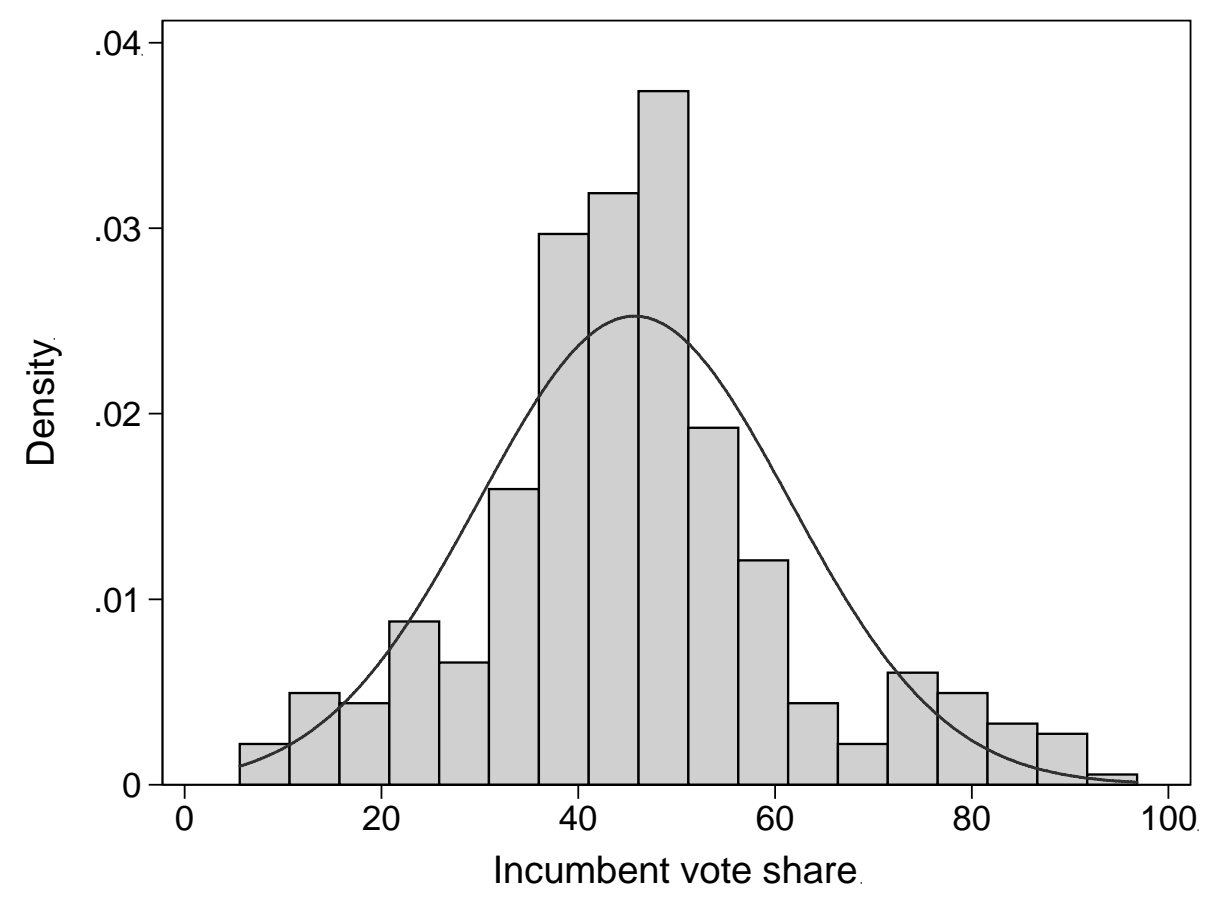

Skewness $=0.44$ 


\section{Endnotes}

${ }^{\mathrm{i}}$ It is known that estimates from an FE and LDV model may be biased, with this bias increasing as T (i.e. number of elections in a country) becomes smaller. One approach to overcoming this source of bias is to use a difference GMM (generalized method of moments) estimator. But these data cannot be fully considered as panels, since we are not following the same incumbents over time. Rather, the incumbent parties change from election to election. Consequently using, for example, an Arellano and Bond estimator with its automatic autocorrelation correction (at two lags of the dependent variable) would be incorrect. The results from several Monte Carlo simulation, however, indicate that, assuming a sound specification, the approach used here in dynamic Model 2 performs "as well or better than more complicated IV estimators " (Adolph, et al., 2005: 18) [see also: Beck and Katz, 2009; Judson and Owen, 1999].

ii Results are not shown, but are available from the authors on request.

${ }^{\text {iii }}$ Results are not shown, but are available from the authors on request.

iv Results are not shown, but are available from the authors on request. 